症例

\title{
腹壁㿂痕ヘルニア内で発症した $\mathrm{S}$ 状結腸腹膜垂による 絞扼性イレウスの 1 例
}

\author{
伊那中央病院外科 \\ 芳 澤 淳一 大久保洋平唐澤 文寿 \\ 中山中竹内信道伊藤憲 雄
}

症例は72歳，女性４0歳頃より腹壁㓔痕ヘルニアを指摘されていた。窩部痛と嘔吐 を主訴に来院した. 左側腹部に直径 $25 \mathrm{~cm}$ の腹壁痏痕ヘルニアを認め, 腹部 CTでは腹 壁瘃痕ヘルニア内にS 状結腸と小腸が脱出していた，小腸の造影効果は軽度低下してい たが, 腸閉塞所見はなかったため, 入院後保存的に加療を行った。 入院 3 日目にも病状 は改善せず, 再度 CT 検査を行ったところ, 脱出小腸の造影効果は消失し, 腸閉塞所見 も出現していたため緊急手術を行った.ヘルニア囊内に下行結腸からS 状結腸が脱出し， さらに $\mathrm{S}$ 状結腸腹膜垂がヘルニア囊に癒着することで小腸 $35 \mathrm{~cm}$ が内ヘルニアとなり壊 死性変化を伴い拡張していた。 腹膜垂を切開して壊死腸管を切除, 腹壁疫痕へルニアの 修復も行った．腹壁㓔痕ヘルニア内で発症した絞扼性イレウスおよび腹膜垂による腸閉 塞はいずれもまれであり, 文献的考察を含めて報告する.

索引用語：腹壁瘏痕ヘルニア, 腹膜垂, 腸閉塞

はじめに

絞扼性イレウスは消化器外科における緊急性を要す る疾患の一つで, 迅速な診断と治療が必要である ${ }^{1)}$. 今回, われわれは腹壁瘢痕ヘルニア内で絞扼性イレウ スを発症した 1 例を経験した。ヘルニア囊内ではS 状 結腸腹膜垂がへルニア囊に瘉着することで，小腸が絞 扼され壊死に陥っていた。いずれの病態もまれである ものの, 早期診断および治療のために, これらの病態 を念頭に置く必要があり, 文献的考察を加えて報告す る.

\section{症例}

患者：72歳, 女性.

主訴 : 心窩部痛, 嘔吐.

既往歴：10歳時に左下腹部の腹壁膿揚の切除を受け ていた. 25歳時に帝王切開と両側卵管結紮術を施行. 当院消化器科にて, 腹水を伴う慢性 $\mathrm{C}$ 型肝硬変に対し て利尿剂，分岐鎖アミノ酸製剤の処方を受けフォロー されていた４0歳頃より左下腹部創部に腹壁疫痕へル

2013年 7 月 4 日受付 2013 年 7 月18日採用

〈所属施設住所〉

厂 399-8555 伊那市小四郎久保1313- 1
ニアを認め, 当初は鶏卵大であったものの徐々に増大

し，70歳頃より直径約 $25 \mathrm{~cm}$ 程度になっていた.

現病歴 : 心窩部痛と嘔吐を主訴に当院を受診した.

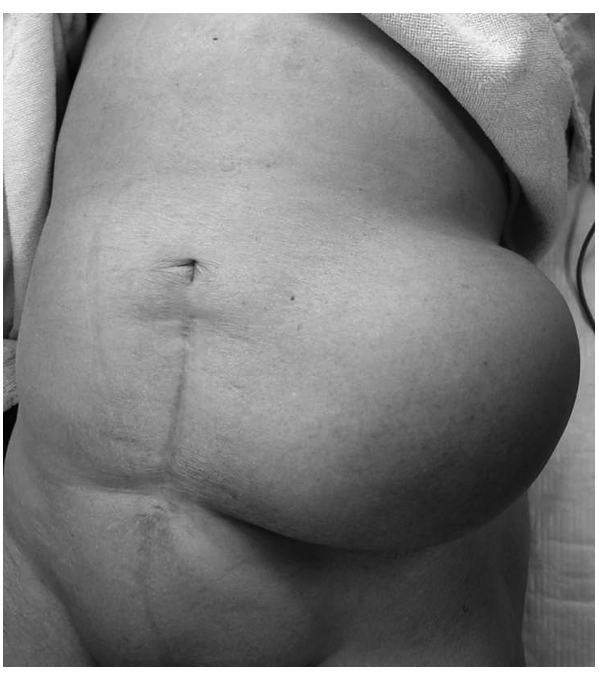

Fig. 1 The patient had an incisional hernia about $25 \mathrm{~cm}$ in diameter in the left lower quadrant of abdomen. 


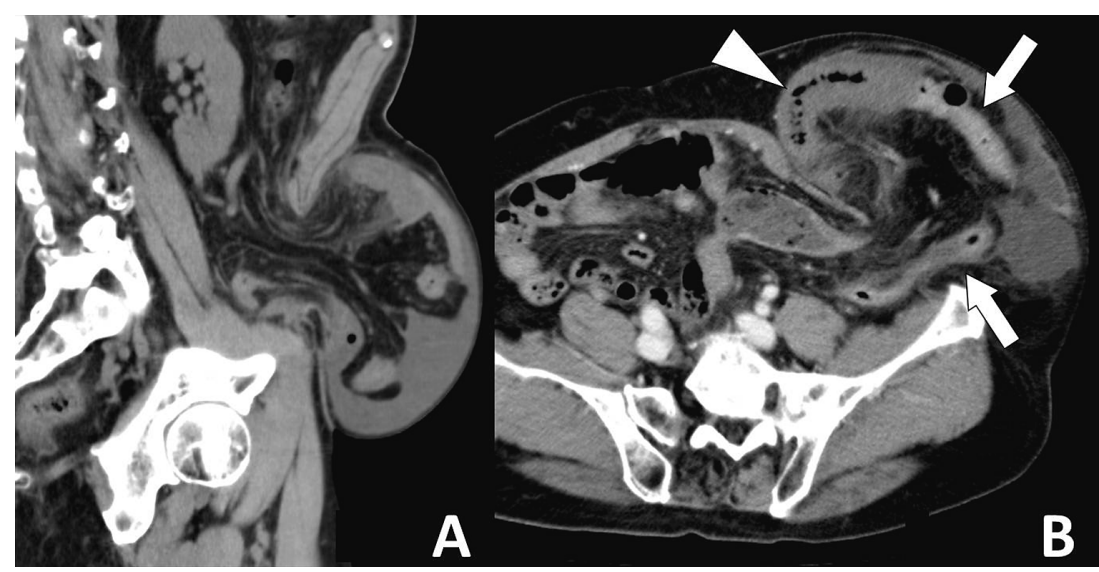

Fig. 2

A. Plain CT (vertical axis) : The sigmoid colon and the small intestine encased in an incisional hernia.

B. Enhanced CT : Enhancement efficacy of the sigmoid colon was normal $(\Rightarrow)$, but that of the small intestine $(\triangleright)$ was slightly reduced in the incisional hernia.

入院時所見：身長 $148.0 \mathrm{~cm}$, 体重 $50.3 \mathrm{~kg}$, 腹部は平坦, 軟. 心窩部に自発痛を認めるものの圧痛は認めなかっ た．左側腹部に直径約 $25 \mathrm{~cm}$ 程度の腹壁㓔痕ヘルニア を認め（Fig. 1），触診上は軟であったが，ヘルニア 内容物の還納は困難であった。下腹部正中と左側腹部 腫脹の下縁に手術痏痕を認めた。体温 $37.0^{\circ} \mathrm{C}$, 心拍数 84 回/分, 収縮期血圧/拡張期血圧 $176 / 102 \mathrm{mmHg}$, $\mathrm{SpO} 2$ 98\% (room air).

入院時血液検査所見 : WBC $6,190 / \mu 1, \quad R B C 392 \times$ $10^{4} / \mu \mathrm{l}$, Hb $10.8 \mathrm{~g} / \mathrm{dl}$, Plt $34.7 \times 10^{4} / \mu 1$, BUN 22.0 $\mathrm{mg} / \mathrm{dl}, \quad$ Cr $0.88 \mathrm{mg} / \mathrm{dl}$, TP $7.2 \mathrm{mg} / \mathrm{dl}$, Alb $3.6 \mathrm{mg} / \mathrm{dl}$, T.bil. $0.89 \mathrm{mg} / \mathrm{dl}, \mathrm{Na} 137 \mathrm{mEq} / \mathrm{l}, \mathrm{K} 4.9 \mathrm{mEq} / \mathrm{dl}, \mathrm{Cl} 102$ $\mathrm{mEq} / \mathrm{dl}$, AST 43IU/l, ALT 22IU/l, LDH 269IU/l, CK 160IU/l， CRP 0.08mg/dl と軽度の貧血を認めた。

入院時腹部造影 $\mathrm{CT}$ : 左側腹部で腹壁が離開し, 腹 壁痏痕ヘルニアとなっていた。ヘルニア内容は小腸と $\mathrm{S}$ 状結腸で囊内に脱出し, 周囲に少量の腹水も認めた. 脱出した小腸は壁肥厚を認め, 造影効果はわずかに認 める程度であったが, S 状結腸の造影効果は良好であ った，肝硬変に伴う肝の萎縮を認めたが，占居性病変 は認めなかった，また，腸閉塞を疑わせるような小腸 の拡張像や鏡面像も認められず, ヘルニア囊以外の腹 䏶に腹水は認められなかった（Fig. 2).

今回発症の 5 力月前に行われた腹部超音波で, 腹壁 瘏痕ヘルニア囊内にも腹水が認められていたこともあ り， CTでの腹水は評価困難であった，また， CTで
ヘルニア内容である小腸の造影効果は低下していた が, 同じくヘルニア内容のS 状結腸は良好に造影され, 腸閉塞を疑う所見もなく, 腹壁瘕痕ヘルニアも触診上， 軟であったことから腹壁瘷痕ヘルニア嵌頓も否定的と 考えた. 胃腸炎と判断し, 鑑別として腹壁㓔痕ヘルニ ア内の小腸虚血, 胃十二指腸潰瘍を考慮し入院とした.

入院後経過 : 入院後, 胃管を挿入の上, 絶飲食, 輸 液を施行した。 入院翌日には38度台の発熱を認め, 心 窩部痛は継続したが，腹部圧痛は認めなかった，腹部 レントゲンでは小腸の拡張像を認めた。 入院翌々日に も38度台の発熱が続き, 腹部掞よび腹壁痏痕ヘルニア の圧痛はなかったものの, 腹壁㓔痕ヘルニアがこれま でよりも緊満して触知された。そのため血液検査なら びに腹部造影 $\mathrm{CT}$ を再度行った。

入院 2 日後の血液検査所見 : WBC 14,530/ $\mu 1, \mathrm{RBC}$ $283 \times 10^{4} / \mu 1$, Hb $7.8 \mathrm{~g} / \mathrm{dl}$, Plt $8.1 \times 10^{4} / \mu$ l, BUN 47.9 $\mathrm{mg} / \mathrm{dl}$, Cr $1.48 \mathrm{mg} / \mathrm{dl}$, TP $5.1 \mathrm{mg} / \mathrm{dl}$, Alb $3.6 \mathrm{mg} / \mathrm{dl}$, T.bil. $1.66 \mathrm{mg} / \mathrm{dl}, \quad \mathrm{Na} 128 \mathrm{mEq} / \mathrm{l}, \quad \mathrm{K} 4.9 \mathrm{mEq} / \mathrm{dl}, \quad \mathrm{Cl} 99$ $\mathrm{mEq} / \mathrm{dl}$, AST 34IU/l, ALT 18IU/l, LDH 224IU/l, CK 173IU/1, PT 15.0sec (47.0\%), PT-INR 1.38, PTT $34.4 \mathrm{sec}, \mathrm{CRP} 11.7 \mathrm{mg} / \mathrm{dl}$ と炎症反応の上昇と腎 機能の悪化, 貧血と血小板減少, PT 延長, 電解質異常, 低蛋白血症を認めた。

入院 2 日後腹部 CT : 腹壁瘏痕ヘルニア内の小腸は 単純 CTでは肥厚した壁が高濃度を呈し, 造影 CTで は造影効果は消失しており出血性梗塞が疑われた。へ 


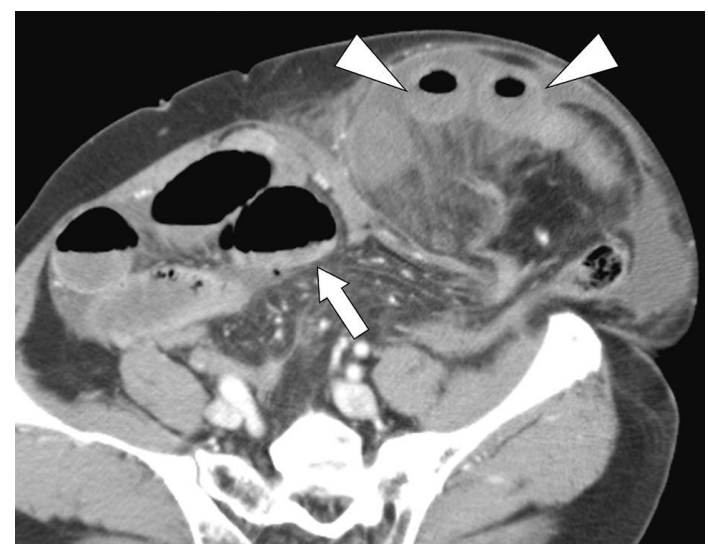

Fig. 3 Abdominal enhanced CT showed disappearance of enhancement efficacy of the encased small intestine $(\triangleright)$ in the ventral hernia, and appearance of findings suggestive of ileus $(\Rightarrow)$.

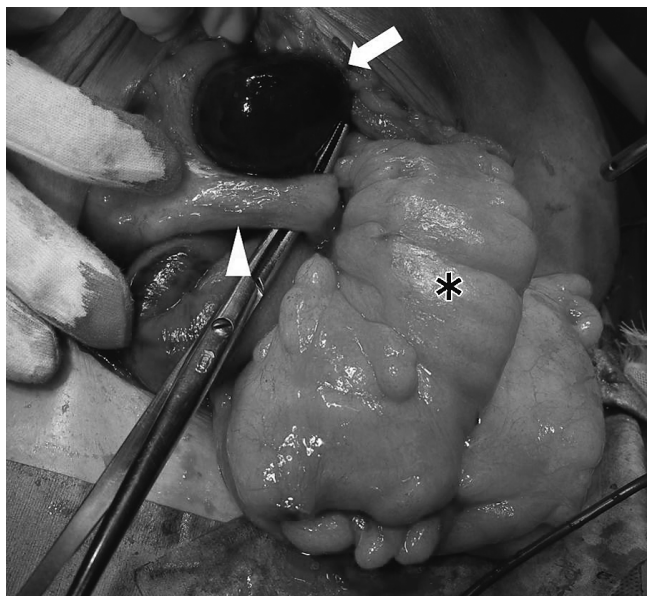

Fig. 4 Epiploic appendage of the sigmoid colon adhereing to the sac caused internal hernia of the small intestine.

* ; sigmoid colon

$\triangleright$; epiploic appendage of the sigmoid colon

$\Rightarrow$; strangulated small intestine

ルニア内部の S 状結腸の造影効果は良好であった．腹 腔内の小腸は拡張し，鏡面像も出現しており腸閉塞の 所見で, 腹腔内には腹水も認めた（Fig. 3).

以上より腹壁瘏痕へルニア内の小腸壊死の診断で緊 急手術を施行した.

手術時所見 : 腹壁㓔痕ヘルニアは縦 $20 \times$ 横 $28 \mathrm{~cm}$ 大 で，ヘルニア下縁にある手術症痕に沿った横切開にて 開始した。ヘルニア囊を開放すると漿液性の腹水を認

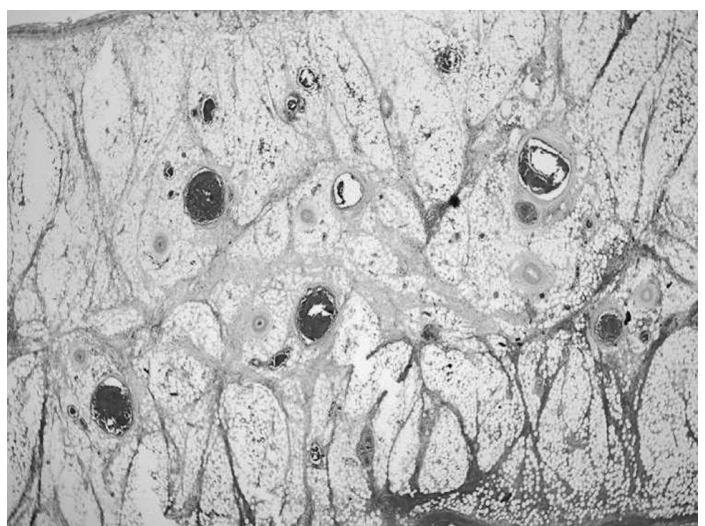

Fig. 5 Pathological findigns : Epiploic appendage was fat tissue with fibrosis and bleeding $(\mathrm{H}-\mathrm{E} \times 20)$.

め, ヘルニア囊内には S 状結腸と, 暗赤色に変色し拡 張した小腸を認めた。 $\mathrm{S}$ 状結腸直径約 $1 \mathrm{~cm}$ 程度の黄 色の索状物がヘルニア囊に伸びて癒着しており，この 索状物と S 状結腸間膜間に小腸が嵌入することで内へ ルニアとなり，小腸の梗塞壊死を引き起こしていた (Fig. 4).ヘルニア囊内のS 状結腸には異常所見は認 められなかった，索状物を切離し，壊死部を含む小腸 約 $35 \mathrm{~cm}$ を切離し，吻合した。ヘルニア門は内側は腹 直筋，頭側および外側では腹横筋並びに腹斜筋，尾側 では鼠径䩲帯で形成されており，これらのへルニア門 を縫合閉鎖した。

病理組織学的検査所見：切除した小腸には著明な出 血や血管拡張，浮腫の虚血性変化が認められ，出血性 梗塞に相当する組織像であった。索状物は線維化と血 管を伴った脂肪組織であった（Fig. 5)。

絞扼性イレウスの原因となった索状物は，手術所見 と病理組織所見とから S 状結腸腹膜垂がヘルニア囊に 癒着したものであると考えられた。

術後経過：術後 2 日目に腸閉塞の増悪を認めたもの の保存的に軽快した。術後 5 日目より経口摂取を開始 し，術後より経口摂取を開始した。その後の経過は良 好で術後11日目に退院した。

\section{考察}

腹壁㓔痕へルニアは, 開腹術後に皮膚切開創が治癒 しても筋膜層が痽痕組織で置換され，腹壁縫合部から 腹腔内容物が脱出するヘルニアで, 発生頻度は 2-11 \%とされる ${ }^{2)}$.腹壁㓔痕へルニアの原因は，全身的要 因として高齢・栄養障害・黄疸・組織の血行障害・糖 尿病・肺疾患・イレウス・腹水・肥満・咳嗽の多発な 
Table 1 Reported cases of ileus due to epiploic appendage in Japan

\begin{tabular}{|c|c|c|c|c|c|c|c|c|c|c|c|}
\hline Case & Author & Year & Age & Sex & $\begin{array}{l}\text { Attached organ } \\
\text { of epiploic } \\
\text { appendage }\end{array}$ & $\begin{array}{l}\text { Form of epiploic appendage } \\
\text { causing ileus }\end{array}$ & $\begin{array}{c}\text { Intestinal resection } \\
\text { (length) }\end{array}$ & $\begin{array}{l}\text { Intestinal } \\
\text { necrosis }\end{array}$ & $\begin{array}{c}\text { Period from } \\
\text { onset to } \\
\text { operation }\end{array}$ & $\begin{array}{l}\text { Previous } \\
\text { laparotomy }\end{array}$ & $\begin{array}{l}\text { Pathological findings of } \\
\text { epiploic appendage }\end{array}$ \\
\hline 1 & $\mathrm{Oka}^{9)}$ & 1985 & 75 & M & Transverse colon & band to cecum & - & - & 6 days & - & $\begin{array}{c}\text { fat tissue with bleeding } \\
\text { and thrombosis }\end{array}$ \\
\hline 2 & Uetake $^{10)}$ & 1995 & 59 & M & Sigmoid colon & loop & - & - & 10 days & - & inflammation and fibrosis \\
\hline 3 & Ogura $^{11)}$ & 1997 & 64 & M & Transverse colon & loop & - & - & unknown & - & fat tissue with fibrosis \\
\hline 4 & Arikawa $^{12)}$ & 2000 & 55 & M & Sigmoid colon & loop & - & - & unknown & - & - \\
\hline 5 & Osada ${ }^{13)}$ & 2001 & 59 & $\mathrm{~F}$ & Transverse colon & band to mesojejumun, jejunum & - & - & 9 days & - & $\begin{array}{c}\text { fat tissue with bleeding } \\
\text { and fibrosis }\end{array}$ \\
\hline 6 & Takada ${ }^{8)}$ & 2001 & 62 & M & Ascending colon & inflammatory mass & - & - & 3 days & - & $\begin{array}{l}\text { inflammatory swelling } \\
\text { with diverticulum }\end{array}$ \\
\hline 7 & Hiroyoshi ${ }^{14)}$ & 2003 & 71 & $\mathrm{~F}$ & Sigmoid colon & band & ileum $(50 \mathrm{~cm})$ & + & 2 days & + & - \\
\hline 8 & Takahashi ${ }^{15)}$ & 2005 & 26 & M & Sigmoid colon & band to urinary bladder & jejunum $(5 \mathrm{~cm})$ & - & 3 days & - & - \\
\hline 9 & & & 67 & $\mathrm{~F}$ & Sigmoid colon & band to mesosigmoidcolon & ileum $(100 \mathrm{~cm})$ & + & 3 days & - & - \\
\hline 10 & Sumi ${ }^{16)}$ & 2007 & 52 & M & Sigmoid colon & loop & ileum $(55 \mathrm{~cm})$ & + & 11 days & - & - \\
\hline 11 & Watanabe $\mathrm{e}^{17)}$ & 2007 & 79 & $\mathrm{~F}$ & Sigmoid colon & band to retroperitoneum & small intestine & - & 44 days & + & - \\
\hline 12 & Sendou ${ }^{18)}$ & 2008 & 61 & M & Sigmoid colon & loop & - & - & 0 day & + & - \\
\hline 13 & Kamimura $^{19)}$ & 2009 & $70 \mathrm{~s}$ & M & Sigmoid colon & adhesion to mesoileocecum & - & - & 0 day & - & - \\
\hline 14 & Homma $a^{20)}$ & 2009 & 63 & M & Sigmoid colon & loop & - & - & 10 days & - & - \\
\hline 15 & Oneyama ${ }^{21)}$ & 2011 & 73 & $\mathrm{~F}$ & Sigmoid colon & loop & - & - & 1 day & - & - \\
\hline 16 & Yada $^{22)}$ & 2011 & 71 & $\mathrm{~F}$ & Transverse colon & band to small intestine & - & - & 15 days & + & - \\
\hline 17 & Ninomiya ${ }^{23)}$ & 2012 & $70 \mathrm{~s}$ & M & Sigmoid colon & adhesion to mesentery proper & ileum $(3 \mathrm{~cm})$ & - & 3 weeks & - & - \\
\hline 18 & Obuchi24) & 2012 & 63 & M & Sigmoid colon & admesion to small intestine & - & - & 0 day & - & fat tissue with bleeding \\
\hline 19 & Our case & & 72 & $\mathrm{~F}$ & Sigmoid colon & band to ventral hernia sac & $\begin{array}{l}\text { small intestine } \\
(35 \mathrm{~cm})\end{array}$ & + & 2 days & + & $\begin{array}{c}\text { fat tissue with bleeding } \\
\text { and fibrosis }\end{array}$ \\
\hline
\end{tabular}

どがあり, 局所的要因として創部の感染・腹壁の不適 切な縫合など多数の要因が複合的に関与して発症する ${ }^{3)}$.

ヘルニア門が大きい場合には慢性的なへルニアとな り, 嵌頓絞扼することは少ない. しかし, ヘルニア門 が小さい場合は嵌頓絞扼の可能性があり, 腹壁痏痕へ ルニアでは嵌頓は $14.6 \%$, 絞扼は $2.4 \% に$ 発症するとさ れる4).

自験例では腹壁瘷痕ヘルニア内部で索状物による絞 扼性イレウスを発症した。医学中央雑誌を中心とし, 1983年〜2013年までを「腹壁誐痕へルニア」「イレウス」 で検索し, 腹壁痏痕へルニア嵌頓を除外すると, 腹壁 㓔痕へルニア内での絞扼性イレウスの発症例は 1 例の 報告を認めるのみで, まれであった5)。この報告では 腹壁痏痕ヘルニアは $15 \times 25 \mathrm{~cm}$ で自験例同様に比較的 大きく, ヘルニア囊内で空腸が上腸間膜動脈を軸に捻 転し, 空腸切除および双孔式空腸瘦が施行されていた. 腹壁痏痕へルニア内で絞扼性イレウスをきたす場合に は, 一定の長さの腸管がヘルニア囊内に脱出し, さら に腸閉塞のために腸管も緊満するため, 腹壁痏痕へル ニアは大きな状態にあると考えられる。

絞扼性イレウスは腸管の機械的な通過障害に加え血 行障害も存在し, 腸管壊死や穿孔, 腹膜炎を合併する こともあり，恩田ら ${ }^{6}$ のイレウス全国集計 21,899 例で
は，死亡率は $7.4 \%$ であったと報告されている。この ため, 迅速かつ的確な診断と速やかな外科的手術療法 が必要である，自験例では腹壁㿍痕ヘルニアの嵌頓は 除外しえたものの, 初回の腹部 CTではイレウス像は 認めていなかったこともあり, 腹壁瘢痕へルニア内で の絞扼性イレウスまでの診断には至らず，その時点で 手術は行えなかった．初回の腹部 CTでヘルニア囊内 に限局した小腸の造影効果が減弱し，腸管壁が肥厚し ていたことにより注意を払えば早期診断できた可能性 はある，比較的大きな腹壁痏痕へルニアでは，嵌頓で なくても腹壁瘏痕へルニア内で絞扼性イレウスを発症 しうることを認識し, 早期診断・治療に努める必要が ある。

腹膜垂は全結腸に存在する漿膜に覆われた脂肪組織 であり, 平均 $3 \mathrm{~cm}$, 約 100 個程度存在しているとされ $ろ^{7}$. 機能は大網と同様の防御作用, 腸管進展時の腸 管壁の血流確保, 腸蠕動の際の緩衝作用, 液体の吸収, 脂肪の貯蔵などがあげられる。

腹膜垂による疾患は, 多くが腹膜垂炎によって惹起 されると報告されている7 . 解剖学的特徵により腹膜 垂には捻転や静脈血栓症が生じやすく, 循環障害や梗 塞などの虚血性変化や, 結腸悡室炎により腹膜垂炎が 発症すると考えられている8 ${ }^{8}$. 
岡ら ${ }^{9)}$ は腹膜垂によってイレウスが発生する機序と して（1）腹膜垂炎により生じた癒着や索状物による 腸管圧迫，（2）これら癒着により屈曲された付着部 腸管の閉塞，（3）腹膜垂炎による炎症性腫瘤による 腸管の直接圧迫，（4）捻転を起こして脱落した腹膜 垂がほかの腸管に癒着，あるいは相対する腹膜垂が互 いに癒着して腸管狭窄を生じる場合に分類している.

医学中央雑誌で, 1983年〜2013年までを「腹膜垂」「イ レウス」で検索すると（会議録は除く）, 腹膜垂が原 因となったイレウスの発症例は自験例を含めて19例の

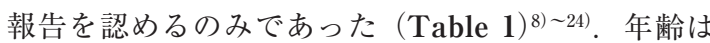
26歳から78歳までであり, 自験例が最高齢であった. 20例中14例が $\mathrm{S}$ 状結腸の腹膜垂が腸閉塞の原因となっ ており最多で，次いで横行結腸の 4 例であった。開腹 歴を有するのは 5 例のみで, 多く（14例）が, 開腹歴 のない症例であった。発症から手術までの期間は 0 日 から44日（平均8.2日）と幅があり，術前診断の困難 さを表している．発症当日に手術できたのは18例中 3 例のみで，ほとんどの症例で胃管やイレウス管などの 腸管減圧処置が行われ保存的治療が開始されていた。 腸閉塞の成因としては自験例を含む10例が腹膜垂と他 臓器との癒着, 7 例で腹膜垂同士が癒着してloop 形成しその間隙に腸管が入り込む形式，1 例が㕰室炎 による腹膜垂腫瘤による腸管の圧迫による腸閉塞であ り，全例で小腸での腸閉塞であった．腸管切除を行っ たのは 7 例で，自験例同様に絞扼壊死をきたしていた のは 4 例であった。原因として, 一般的な術後の癒着 や索状物は線維性成分からなる一方で，腹膜垂は腹膜 垂炎を発症して癒着や索状化しても脂肪組織が主であ り, 比較的伸展性が保たれていることが推測された。 7 例で腹膜垂の病理組織学的検索が行われており, 憩 室炎による腫瘤形成例を除いて, 線維化, 出血を伴っ た脂肪組織であり，脂肪垂炎を反映している可能性も ある。

腹膜垂による腸閉塞の診断はCT やイレウス管造影 検査，超音波検査などで行われているが，イレウスの 原因が腹膜垂であると診断できた報告は 1 例のみ ${ }^{8)}$ あり，多くが開腹所見で明らかとなっている．術前診 断は困難であることが多く，原因が明らかでない腸閉 塞では腹膜垂による腸閉塞も鑑別に入れ診療に当たる 必要がある。開腹歴の有無にかかわらず，腹部 CTで 腸閉塞の原因部位が結腸（特にS 状結腸）に隣接して いるような場合には，腹膜垂による腸閉塞を考慮する 一助となる可能性もある.

\section{結語}

腹壁痏痕へルニア内で, 腹膜垂が原因となった絞扼 性イレウスを発症した 1 例を経験した。腹膜垂が原因 となった絞扼性イレウス，腹壁痏痕へルニア内での絞 扼性イレウスともにまれな病態である。早期診断と治 療のためには腹壁瘢痕へルニアでは嵌頓以外でも腸管 の絞扼・壊死をきたすこともあることを念頭に置く必 要がある。ささらに，原因が明らかでない腸閉塞では腹 膜垂による腸閉塞も鑑別に入れ診療に当たる必要があ る.

なお, 本文の要旨は第74回日本臨床外科学会総会に おいて発表した。

\section{文献}

1）山田武史, 菅 隼人, 松本智司他：機械的イレウ ス 複雑性または絞扼性イレウス 絞扼性イレウス 早期診断の重要性. 外科 $2012 ; 74: 361-365$

2) Mudge M, Hughes LE : Incisional hernia : a 10 year prospective study of incidence and attitudes. Br J Surg $1985 ; 72: 746-750$

3）石川 宏: 腹壁疲痕ヘルニア. 冲永功太編, ヘル ニアのすべて, ヘルス出版, 東京, 1995, p187 $-196$

4) Read RC, Yonder G : Recent trends in the management of incisional herniation. Arch Surg $1989 ; 124: 485-488$

5）福原研一朗, 大村 泰, 葛城邦浩他：ヘルニア囊 内で空腸捻転をきたした腹壁癜痕へルニアの 1 例. 日臨外会誌 $2009 ; 70: 253-256$

6）恩田昌彦, 高崎秀明, 古川清憲他：イレウス全国 集計 21,899 例の概要. 日腹部救急医会誌 2000 ; $20: 629-636$

7) Lynn TE, Dockerty MB, Waugh JM : A clinicopathologic study of the epiploic appendages. Surg Gynecol Obstet 1956 ; 103 : 423-433

8）高田知明, 吉田秀明, 塚田守雄他 : 腸閉塞症を合 併した原発性腹膜垂炎の 1 例. 日消外会誌 $2001 ; 34: 1326-1330$

9）岡 統三, 河野暢之, 谷口勝俊他 : 腹膜垂炎によ る腸閉塞の 1 例. 日臨外会誌 $1985 ; 46: 624-$ 628

10）植竹宏之, 松峯敬夫, 渡辺一晃他：腹膜垂による 絞扼性イレウスの 1 例. 日腹部救急医会誌 $1995 ; 15: 1135-1138$

11）小倉德裕, 印牧俊樹, 平充他：腹膜垂炎によ 
る小腸閉塞の 1 例. 消外 $1997 ; 20: 1425-1430$

12）有川俊治, 長谷川智已, 大原忠敬他 : 腹膜垂によ る腸閉塞の 1 例. 臨外 $2000 ; 55: 1347-1349$

13）長田俊一, 高橋徹也, 福島忠男他 : 腹膜垂による イレウスの 1 例. 日臨外会誌 $2001 ; 62: 2697$ 2700

14）廣吉基己，荻野和功，黒田大介他：腹膜垂による 絞扼性イレウスの 1 例. 日臨外会誌 2003；64： $1650-1653$

15）高橋保正, 長田 明, 大河内信弘：腹膜垂による 絞扼性イレウスの 2 例. 日臨外会誌 $2005 ; 66$ ： $2213-2217$

16）寿美哲生, 勝又健次, 村越雄介他：腹膜垂による 絞扼性イレウスの 1 例. 日本大腸肛門病会誌 $2007 ; 60: 100-104$

17）渡邊龍之, 永田 威, 田村美歩他：腹膜垂による 腸閉塞の 1 例. 日消誌 $2007 ; 104: 1480-1485$

18）千堂宏義, 西村 透, 中村吉貴他：腹膜垂によ る絞扼性イレウスの 1 例. 日消外会誌 2007 ; $40: 1711-1715$
19）上村眞一郎, 荒瀬光一, 森田圭介他：腹膜垂によ る絞扼性イレウスの 1 例. 臨外 2009；64:1601 $-1604$

20）本間祐樹, 小尾芳郎, 上向伸幸他 : $\mathrm{S}$ 状結腸腹膜 垂による小腸イレウスの 1 例. 日臨外会誌 $2010 ; 71: 119-122$

21）小根山正貴, 関川浩司, 後藤 学他: S 状結腸腹 膜垂による内ヘルニアの 1 例. 日臨外会誌 $2011 ; 72: 3175-3179$

22）矢田一宏, 平野誠太郎, 平尾悦郎他 : 横行結腸腹 膜垂による腸閉塞の 1 例。外科 $2011 ； 73: 439$ $-442$

23）二宮繁生, 白下英史, 坂東登志雄他 : S 状結腸腹 膜垂による腸閉塞症の 1 例。外科 $2012 ; 74$ ： $778-781$

24）大㴊 徹, 亀山哲章, 冨田眞人他 : 腹腔鏡下イレ ウス解除術を施行した S 状結腸腹膜垂による絞扼 性イレウスの 1 例. 日内視鏡外会誌 $2012 ; 17$ : $815-819$

\title{
A CASE OF STRANGULATED ILEUS DUE TO EPIPLOIC APPENDAGE OF THE SIGMOID COLON IN AN INCISIONAL HERNIA
}

\author{
Junichi YOSHIZAWA, Yohei OKUBO, Fumitoshi KARASAWA, \\ Ataru NAKAYAMA, Nobumichi TAKEUCHI and Norio ITO \\ Department of Surgery, Ina Central Hospital
}

A 72-year-old woman visited our hospital because of epigastralgia and vomiting. She had had an incisional hernia about $25 \mathrm{~cm}$ in diameter at the left lower quadrant of abdomen since around 40 years of age. Abdominal enhanced CT scan showed the sigmoid colon and the small intestine to have protruded into the incisional hernia, and enhancement efficacy of the small intestine was slightly reduced. However, there were no findings indicative of ileus, so we treated her conservatively after medical treatment. On the 3rd hospital day, no symptomatic remission was gained and abdominal enhanced CT scan showed disappearance of enhancement efficacy of the protruded small intestine into the incisional hernia and appearance of findings of ileus. We performed emergency operation. During the operation, the descending colon and the sigmoid colon protruded into the incisional hernia, and epiploic appendage of the sigmoid colon adhering to the sac caused strangulation of the small intestine. We performed dissection of the adhering epiploic appendage, small bowel resection, and repair of the incisional hernia.

There have been few reports of ileus in an incisional hernia or strangulated ileus caused by epiploic appendage. We report our case, along with review of the relevant literature.

Key words : incisional hernia, epiploic appendage, ileus 